\author{
Erdei-Derschner Katalin
}

\title{
„PÉNZÉRT VALÓDI ÉRTÉKET” ELV ALAPÚ KÖZBESZERZÉSEK
}

\author{
Value for Money (VFM) Principle Based Public Procurements
}

Erdei-Derschner Katalin, PhD-hallgató, Nemzeti Közszolgálati Egyetem, Közigazgatástudományi Doktori Iskola, erdei.derschner@gmail.com

A hatékonyság, mint kulcsfontosságú fogalom, elötérbe kerülésével az állami szektorban mára már elvárás, hogy minden közpénzköltés megfeleljen a „pénzért valódi értéket” (value for money) elvnek, a verseny tisztasága, az átláthatóság, a nyilvánosság és a többi közbeszerzési alapelv mellett. Az Európai Parlament és Tanács 2014/24/EU irányelv hazai implementációnak köszönhetöen a 2015-ben hatályba lépett közbeszerzésröl szóló törvénybe is bekerült a legelönyösebb ár-érték elve mint lehetséges bírálati szempont. Ezzel megalapozta a "pénzért értéket" elv alapú beszerzés lehetöségét hazánkban is. A bírálati szempont azonban csak egy része a teljes koncepciónak. A tanulmány célja, hogy a rendelkezésre álló iránymutatásokon keresztül bemutassa az elv sokrétüségét, a beszerzési gyakorlatba való átültetési lehetőségeit és korlátait is.

\section{KulcsszavaK:}

beszerzés értékteremtő funkciója, hatékonyság, költségelemzési technikák, „pénzért értéket” elv

Because of the efficiency focus in the public sector, all public spending is now expected to comply with the "value for money" principle, along with fair competition, transparency and publicity and other public procurement principles. Due to the domestic implementation of the Public Procurement Directive 2014/24/EU of the European Parliament and Council, the new Hungarian public procurement law (Act CXLIII of 2015 on Public Procurement) contains the "value for money" principle as one of the possible contract award criteria. With this, the possibility of purchasing based on the "value for money" principle has been established in Hungary, as well. However, the MEAT (most economically advantageous tender criteria) is only a part of the overall concept. The aim of the article is to show the diversity of the principle, the possibilities and limitations of its application into the procurement practice through the available guidelines.

Keywords:

cost analysis techniques, efficiency, the "value for money" principle, value added procurement 


\section{BEVEZETÉS}

Az Európai Parlament és Tanács 2014/24/EU irányelvének 67. cikkelye kimondja, hogy „az ajánlatkérő szervnek a gazdaságilag legelőnyösebb ajánlat szempontjára kell alapoznia a közbeszerzési szerződések odaítélését”. ${ }^{1}$ A gazdasági legelőnyösebb ár fogalmát gyorsan átültették a magyar közbeszerzési törvénybe, és már a 2015. évi CXLIII. törvényben a közbeszerzésről ${ }^{2}$ (Kbt.) megjelent, mint a nyertes ajánlattevő kiválasztásnak egyik módja. A Kbt. 76. \$ (2) bekezdése alapján 2015. november 1-jétől az ajánlatkérők a közbeszerzési eljárás során az alábbi három értékelési szempont közül választhatnak: a legalacsonyabb ár; a legalacsonyabb költség, amelyet az ajánlatkérő által meghatározott költséghatékonysági módszer alkalmazásával kell kiszámítani; a legjobb ár-érték arányt megjelenítő olyan - különösen minöségi, környezetvédelmi, szociális - szempontok, amelyek között az ár vagy költség is szerepel.

Bizonyos eljárástípusoknál, mint a versenypárbeszéd, az innovációs partnerség és a hirdetmény nélküli tárgyalásos eljárás a törvényi szabályozás kötelezővé teszi a legjobb árérték arány alkalmazását. ${ }^{3}$

Ezzel a lehetőséggel hazánkban is letették az alapjait, és megteremtették a lehetöségét a "pénzért valódi értéket” elv alapú közbeszerzési gyakorlatnak. Magyarországon is előfordul, hogy az elvet a „VFM” rövidítéssel tüntetik fel, ami a „value for money” angol megnevezés rövidítéséből származik.

\section{AZ ELV ALKALMAZÁSÁNAK JELENTŐSÉGE}

Az elv elöször a versenyszektorban jelent meg, multinacionális vállalatok már több évtizede alkalmazzák, nem csak beszerzési területen. A közszektort érő növekvő nyomásnak és kihívásoknak köszönhetően az elmúlt évtizedben az állami szféra is egyre szélesebb körben kezdte el alkalmazni. Élen jár ebben például az Egysült Királyság, ahol külön szektorspecifikus útmutatások mellett központilag alakították ki az elvhez tartozó beszerzési gyakorlatot. A közbeszerzések területén is megjelent az elv alkalmazására vonatkozó elvárás. A költségvetési korlátok, de növekvő társadalmi igény mellett a beszerzéstől már nemcsak azt várták el, hogy a szükséges árukat, szolgáltatásokat, beruházásokat csak egyszerüen a legjobb áron vásárolják meg, hanem elvárás lett, hogy más szempontokat is, mint például a fenntarthatóságot, szociális szempontokat vagy a kis- és középvállalkozások elönyhöz juttatását, az innovációk elősegítését is figyelembe vegyék.

Az elv alkalmazásának létjogosultsága megkérdőjelezhetetlen, fontossága kiemelkedő. A közpénzek elköltésével szemben nemcsak európai uniós, hanem általános társadalmi

Az Európai Parlament és a Tanács 2014/24/EU irányelve (2014. február 26.) a közbeszerzésről és a 2004/18/EK irányelv hatályon kívül helyezéséről.

2015. évi CXLIII. törvény a közbeszerzésekről (Kbt.).

Kbt. 76. \$. 
elvárás is, hogy minden közületi szerv biztosítsa a termék és szolgáltatás beszerzései során a legjobb ár-érték arányú kimenetet. ${ }^{4}$ Ezen elvárások a hazai szabályozásban, a közbeszerzési alapelvekben is jelen vannak, mint a verseny tisztasága, átláthatósága, nyilvánossága, hatékony és felelős gazdálkodás a közpénzek felhasználásában. ${ }^{5}$

Magyarországon a 2019. évi hivatalos közbeszerzési statisztika szerint az adott évben az ajánlatkérők összesen 9837 db eredményes közbeszerzési eljárást folytattak le 3430 milliárd forint értékben. A 2008 és 2019 közötti időszakot vizsgálva a közbeszerzések átlagosan a GDP 6,6\%-át tették ki. ${ }^{6}$ Ez azonban még csak egy része a teljes közpénzekböl történő beszerzések összértékének. Egyes becslések szerint a teljes közületi beszerzési piac akár a GDP 10-15\%-át is kiteheti, így az állami kiadások a fejlődő országok legnagyobb piaca. ${ }^{7}$ Éppen ezért, az ilyen jellegű pénzek stratégiai célkitűzéseknek megfelelően való felhasználása nélkülözhetetlen az állam gazdaságpolitikai céljainak eléréséhez. ${ }^{8}$ Így elvitathatatlan azon állítás, amely szerint az európai államok és szervezetek felelőssége, hogy az áruk és szolgáltatások előállítása és beszerzése során elősegítsék az innovációt és a kutatás-fejlesztést. ${ }^{9}$

Szintén fontos kiemelni, hogy az uniós támogatásokból megvalósuló projekteknél kötelező a közbeszerzési eljárás alkalmazása. Magyarországon, 2007 és 2013 között 63 ezer fejlesztés valósult meg a 8200 millárd Ft-os uniós támogatásból, amely 2020 végéig további 8300 milliárd Ft támogatási összeggel nőhet. ${ }^{10}$ A támogatásoknál és a fejlesztési alapok felhasználásánál is kötelező elvként kell érvényesülnie annak az irányelvnek, hogy ezeket az alapokat a lehető leghatékonyabban használják, és ehhez elkerülhetetlen a pénzért értéket elv tényleges alkalmazása. ${ }^{11}$

\section{FOGALMI KERETEK}

A törvényi szabályozás a pénzért valódi értéket elvet egyszerüen a legelőnyösebb gazdasági ajánlat fogalmával ragadta meg, ennél azonban a tényleges jelentése sokkal többrétü. Amennyiben mint fogalmat szeretnénk definiálni, jelenleg nincs rá egyetlen, általánosan elfogadott definíció sem, azonban a rendelkezésre álló iránymutatásokból könnyen felépíthetők a fogalmi keretei.

4 Draft recommendation of the Council on fighting bid rigging in public procurement. $C(2012) 115-C(2012) 115$ / CORR1, OECD, 2012. 1.

Kbt. 1. \$.

Beszámoló az Országgyülés részére. Közbeszerzési Hatóság, 2019. 12.

Alfonso Antonio - Ludger Schuknecht - Vito Tanzi: Public sector efficiency: Evidence for new EU member states and emerging markets. European Central Bank Working Paper No. 58, ECB, 2006. 2152.

8 Alban D. Mchopa: Integrating Contract Management Practices into the Achievement of Value for Money in Tanzania Public Procurement: Evidence from Selected Procuring Entities in Moshi Municipalit. Journal of Public Procurement, 15. (2015), 2. 129-149.

9 João Costa: The EU Procurement Directive. IMSTA, Dublin, 2015.

$10 A z$ EU és az Ön pénze. Európai Bizottság Magyarországi Képviselete, 2018. 1.

11 John Bourn: Getting Value for Money from Procurement. UK, National Audit Office, 2001. 3. 
Az angliai Office of Government Commerce (OGC) meghatározása alapján a pénzért értéket elv megvalósulása nemcsak a legalacsonyabb ár elérését jelenti, hanem a minőség és a teljes életköltség optimális arányának megvalósítását a közbeszerzési eljárások során. ${ }^{12}$

A szigetországi National Audit Office (NAO) az elv megvalósításának lényegét szintén az erőforrások optimális felhasználásában látja a kívánt cél elérése érdekében. Itt, mint fontos kitétel már megjelenik a kívánt kimenethez való viszonyítás. ${ }^{13}$ További meghatározás szerint az elv megvalósulása attól függ, hogy a beszerzés során a versenyt és az innovációt megfelelőképpen tudják-e kombinálni. ${ }^{14}$

Leggyakrabban a fogalmi meghatározást a teljesítménymenedzsment területéről átvett „3E” kifejezéshez kötik, azaz az eredményesség (effectiveness), hatékonyság (efficiency) és gazdaságosság (economy) fogalmi háromszögéhez. Egyre gyakrabban egészül ki ez a fogalmi keret egy 4. „E”-vel, a méltányossággal (equity), ami a közbeszerzések esetében kiemelten releváns. Ezt a terminológiát követi az OECD is. Hivatalos útmutatóban a „pénzért értéket” elv alapú beszerzést úgy határozza meg, mint a megfelelő középút megtalálása a „4E” között. ${ }^{15}$

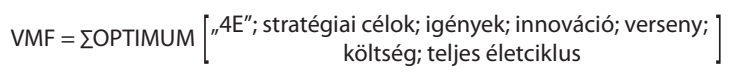

\section{1. ábra • A „pénzért értéket” elv definíciós kerete (Forrás: a szerző szerkesztése)}

Az írországi IMSTA szervezet meghatározása a legátfogóbb. Szerintük az elv alkalmazása nem más, mint az erőforrások arányos, hatékony és eredményes felhasználása az egész beszerzési életciklus alatt, figyelembe véve a kívánt kimeneteket (gazdasági, társadalmi és szektor- vagy szervezetspecifikus célokat), a vevői igényeknek megfelelően. ${ }^{16}$

\section{A BESZERZÉSI FUNKCIÓ ÉRTÉKTEREMTÖ KÉPESSÉGÉNEK FEJLŐDÉSE}

A pénzért értéket elv alakulását megvizsgálhatjuk a beszerzési funkció értékteremtő pozíciójának fejlődésén keresztül is. Ilyen értelemben megkülönböztetünk hagyományos beszerzést, stratégiai beszerzést és pénzért értéket elv alapú beszerzést. A beszerzési funkció fejlődésével a költségelemzési módszerek is folyamatosan fejlődnek, ezzel is

\footnotetext{
Office of Government Commerce (OGC): Working together to deliver better value. London, 2010.

National Audit Office (NAO): Getting value for money from Procurement. London, NAO Information Centre, 2001. 3.

Bourn (2000) i. m. 1-15.

15 Penny Jackson: Value for Money and International Development: Deconstructing Myths to Promote a More Constructive Discussion. OECD, 2012. 1-4.

16 Costa (2015) i. m. 1.
} 
szolgálva a beszerzés értékteremtő funkcióját. Fontos azonban kiemelni, hogy a különböző fázisok nem egymást kizáró módozatok, hanem egymást kiegészítő lehetőségek tárháza.

Míg a hagyományos beszerzés elsősorban egyedül a számvitelileg mérhető költségek csökkentésére fókuszál, addig a stratégiai beszerzés, mint ahogy a neve is mutatja, a beszerzési stratégián keresztül már támogatja szervezeti célkitűzéseket. A pénzért értéket elv alapján működő beszerzés pedig nemcsak támogatja a szervezeti stratégiát, hanem müködésével is megpróbál pozitív befolyást gyakorolni rá. A hagyományos, a stratégiai és a pénzért értéket elvet követő beszerzési szervezet különböző érettségi fokon helyezkednek el, azonban a költségcsökkentés mint cél nem veszett ki egyik modellből sem, hiszen minden szervezet alapvető célja, hogy a rendelkezésre álló erőforrásokat a lehető leggazdaságosabban használja fel.

A hagyományos beszerzés a szükséges alapanyagok és szolgáltatások biztosítása mellett, szinte kizárólag a lehető legmagasabb megtakarítás elérésére törekszik, ezért a költségelemzési technikák közül is leggyakrabban az egységárszámítást alkalmazza (PPU - Price Per Unit), és az egységárral számolt megtakarításokat követi. Fejlettebb szinten már a hagyományos beszerzés eszköztárában is megjelennek a beszállítói és a piacelemzési technikák.

A stratégiai beszerzés keretein belül müködő beszerzési szervezet, a hagyományoshoz képest, már egy magasabb érettségi szinten áll. A beszerzés a szervezet teljes kiadási oldalát kezeli. Ennek elérése érdekében gyakran szerepel az ilyen típusú beszerzési szervezet célkitűzései között olyan mérőszám, mint a szervezeti költségek minél nagyobb arányú beszerzés általi lefedettsége. A beszerzési szervezet a leghatékonyabb eredmény elérése érdekében elemzi, csoportosítja a teljes vállalati költségportfóliót, igény- és specifikációelemzéssel a hatékony és gazdaságos fogyasztás felé próbálja az igénylői oldalt terelni. Napi szinten alkalmazza a kategóriamenedzsmentet, méri a beszállítók teljesítményét, és arról visszajelzést is ad. Költségtechnikák között szerepel a teljes beszerzési költség alapú (TCA - Total Cost of Acquisition) számítás, azaz amikor a termék egységárának kiszámításához már nemcsak a beszerzési egységárat veszik alapul, hanem minden olyan költséget beleszámítanak, ami a megrendelés beszállításáig felmerül, ideértve a szállítás, vám, esetleges raktározási költségeket is. Egyre gyakrabban használják a teljes életciklus (TCO - Total Cost of Ownership) költségszámítási módszert is. E költségelemzési technika során a termék vagy szolgáltatás teljes élettartama alatt felmerülő összes költséget megpróbálják összegyűjteni, számszerüsíteni és a beszerzési döntést ezek alapján meghozni.

A beszerzési szervezet jelenleg legérettebb formája a pénzért értéket elv alapú működési keretek között funkcionáló egység, amelynek elsődleges célja az értékteremtés. Az eredményesség, a gazdaságosság, az egyenlőség és a hatékonyság elérésén túl az ilyen típusú szervezeteknél kiemelt szerepet kap az ilyen típusú versenyelőny legnagyobb mértékű kihasználása, az innováció támogatása, minden érintett féllel való együttmüködés pozitív hatásainak realizálása és a „jó kereslet” ösztönzése. Az alkalmazott költségelemzési technikák között már megjelenik a teljes értékmenedzsment (TVM - Total Value Management) is. A teljes értékmenedzsmentnek ez csak egy lehetséges költségfelbontása, a talán leginkább elterjedtnek tekinthetö. 
Egy másik megközelítést adnak Smock és szerzőtársai, akiknek elmélete a vállalati értékmodellen ${ }^{17}$ alapszik, és öt szintet különböztet meg a költségelemzési technikák között: árközpontút; költség- és értékközpontút; teljes életút költségszámítás alapút; befektetett tőke megtérülés ráta alapút (ROIC) és végül ROIC és versenyképes intelligencia központút. ${ }^{18}$

Ebben az esetben a beszerzés, a szervezeti célok tükrében hozza meg döntéseit, figyelembe véve a kockázatokat, a korlátokat és a lehetséges negatív kimeneteket (például büntetések, környezetszennyezés stb.) is, amiket számszerüsít is. Alkalmazza a különböző döntéselemző eszközöket, egy döntést megelőzően akár több „projektelnyerési” forgatókönyvet is felállít, azok hatását vizsgálja, számszerüsíti.

1. táblázat • A beszerzés értékteremtö funkciójának és költségelemzési technikáinak fejlödése a „pénzért valódi értéket” elv tükrében (Forrás: a szerző szerkesztése)

\begin{tabular}{|l|l|}
\cline { 2 - 3 } \multicolumn{1}{l|}{ Fókusz } & \multicolumn{1}{c|}{$\begin{array}{c}\text { Hagyományos } \\
\text { beszerzés }\end{array}$} \\
\cline { 1 - 1 } Cél & $\begin{array}{l}\text { Költség } \\
\text { Eöltségcsökkentés, } \\
\text { készlethiányok } \\
\text { elkerülése }\end{array}$ \\
\hline $\begin{array}{l}\text { Beszállító- és } \\
\text { piacelemzés }\end{array}$ \\
\hline
\end{tabular}

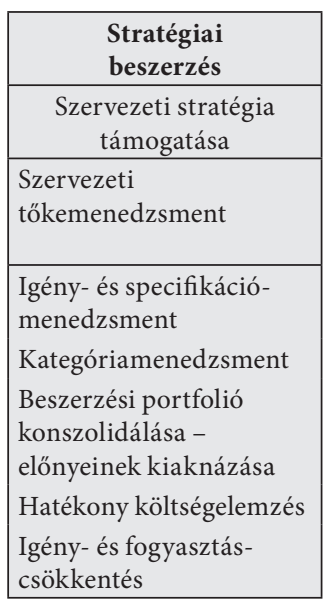

\begin{tabular}{|l|}
\hline \multicolumn{1}{|c|}{$\begin{array}{c}\text { VFM-alapú } \\
\text { beszerzés }\end{array}$} \\
\hline $\begin{array}{c}\text { Szervezeti stratégia pozitív } \\
\text { irányú befolyásolása }\end{array}$ \\
\hline Értékteremtés \\
Versenyelőny kihasználása \\
Együttműködés \\
„Jó” kereslet ösztönzése \\
4„E”
\end{tabular}

\begin{tabular}{|l|}
\hline Egységár \\
alapú \\
beszerzés \\
Price \\
Per Unit \\
(PPU) \\
Termék- \\
egységre \\
levetített \\
beszer- \\
zési ár \\
\hline
\end{tabular}
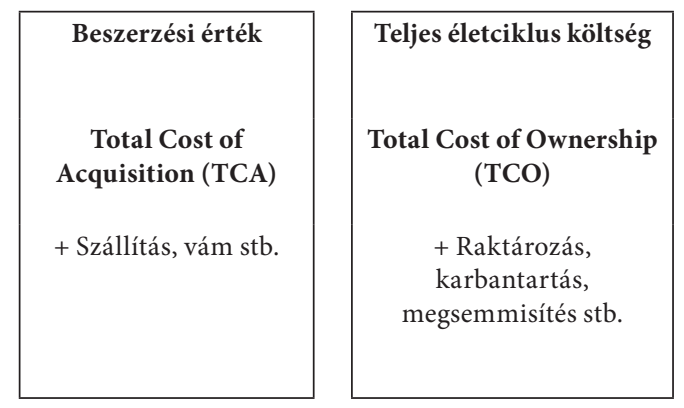

\begin{tabular}{|c|}
\hline Értékmenedzsment \\
Total Value Management \\
(TVM) \\
+ Viszonyítás a szervezeti/ \\
ágazati/nemzeti stratégiai \\
célokhoz, az adott kategória \\
értékteremtó képességét \\
figyelembe véve
\end{tabular}

Corporate Value Model.

18 Robert A. Rudzki - Douglas A. Smock - Stephen C. Rogers: On-Demand Supply Management: World Class Strategies, Practices, and Technology. Fort Lauderdale, J. Ross Publishing, USA, 2007. 5. 
Összefoglalva, tehát a „pénzért értéket elv” alapú beszerzés nem egy egységes módszer, egy egyszerüen leírható definíció, vagy egy kottaként követhető technika, amit minden szervezet és beszerzési funkció esetében ugyanúgy kell alkalmazni, sokkal inkább egy jövőorientált gondolkodásmód, egy munkamódszer, amelynek legfőbb célkitűzése az értékteremtés.

Fontos kiemelni, hogy ez nem egy kizárólagos módszer, hanem magában foglalja az összes eddigi beszerzési és költségelemzési technikát is. A beszerzési szakembereknek ebben az esetben ismerniük kell a különböző költségkategóriákat (ennek egyik lehetséges eszköze a Krajlic-mátrix), és minden egyes termékcsoport tulajdonságához a legmegfelelőbb módszert kell választania, figyelembe véve a szervezeti stratégiát is.

A beszállítómenedzsment a szerződésmenedzsment az elektronikus beszerzések támogatása, a teljesítménymenedzsment széles körü alkalmazása mind olyan eszköz a beszerzés kezében, amelynek körültekintő alkalmazásával az értékteremtés szolgálatába állíthatja müködését.

\section{KIHÍVÁSOK ÉS KORLÁTOK}

Azon szervezeteknek, amelyek elkötelezik magukat az értékteremtő szemléletmód mellett, számos nem leküzdhetetlen akadállyal kell szembenézniük. Egyrészről, sajnos a mai napig korlátot jelentenek a jelenlegi törvényi szabályozás keretei, amelyek nem biztosítanak elég lehetőséget és időt a megfelelő „minőségü” közbeszerzések lefolytatására. További jelentős probléma, hogy a közbeszerzések már így is drágábbak a közbeszerzési eljárás nélkül lefolytatott társaikhoz képest, és a fenti elv bevezetése és működtetése a közbeszerzési funkció működési költségét nézve további pluszköltségekhez vezet, a megnövekedett munkaórának és a képzett beszerzői háttér kiépítésének köszönhetően. Mindemellett véleményem szerint a jelenlegi beszerzési képzés is hiányos hazánkban. A közbeszerzési képzés továbbra is csak „jog” fókuszú, míg a beszerzési részére képzés alig fellelhetö, általában az is csak néhány napos továbbképzés keretein belül.

A mérés, mérhetőség, auditálás és riportálás a következő nehézség. Egy jól, megbízhatóan működő rendszer mögött egy valós, hiteles adatokra építő mérési, riportálási rendszerre van szüksége, amely megfelelő minőségủ valós idejü adatokat szolgáltat minden érintett fél számára. A beszerzési tevékenység mérése során vannak könnyen számszerüsíthető, általában számviteli adatokon alapuló mérőszámok, amelyek alkalmazása mára széles körben elterjedt (ilyenek például a megtakarítások mérése, a súlyozott fizetés határidő vagy a beszállítási határidő mérése). Ezek mind jó alapként szolgálnak egy fejlettebb mérési rendszer kidolgozásához, azonban az értékteremtő beszerzési szervezetnek már olyan mutatókat is ki kell dolgoznia, amelyek például a beszerzések során alkalmazott szállítási módok szén-dioxid-kibocsátását méri, értékeli és visszajelzést ad azokról.

A megvalósítás elkezdéséhez nem kell azonban egy ennyire kifinomult rendszerrel rendelkezni, hiszen már apró változtatások is jelentős eredményre vezethetnek. A következő felsorolás, a teljesség igénye nélkül, néhány ötlettel szolgál: 
- azonos költségszinten jobb minőségű áru/szolgáltatás beszerzése;

- szükségtelen hibás beszerzések elkerülése;

- felhasználói igények kielégítése, de túl nem lépése;

- a beszerzési igény pontos meghatározása, annak érdekében, hogy a beszállítók költséghatékony, innovatív megoldásokat javasolhassanak;

- a versenyt támogató eljárások előnyben részesítése;

- összetettebb projektek esetén törekedni kell legalább a teljes életciklus alapú költségelemzési módszer alkalmazására;

- szervezeten belüli, illetve kívüli ösztönzők bevezetése a jobb ár / jobb minőségű szolgáltatás elérésének érdekében;

- szervezeten belüli, beszerzést érintő folyamatok racionalizálása;

- beszállító-, szerződés- és beszerzési kategóriamenedzsment megfelelő alkalmazása a teljes szervezeti költségportfólión.

A beszerzés értékteremtő szintre emelése a közszférában is elkerülhetetlen, megvalósítása nehézségekkel teli, azonban hatása és eredményei nélkül a célkitűzések elérése lehetetlen. 


\section{FELHASZNÁLT IRODALOM}

1. Alfonso, Antonio - Schuknecht, Ludger - Tanzi, Vito: Public sector efficiency: Evidence for new EU member states and emerging markets. European Central Bank Working Paper No. 58, ECB, 2006. Elérhető: www.ecb.europa.eu/pub/pdf/scpwps/ecbwp581. pdf (A letöltés dátuma: 2017. 10. 15.)

2. Beszámoló az Országgyülés részére. Budapest, Közbeszerzési Hatóság, 2019. Elérhető: https://kozbeszerzes.hu/data/filer_public/89/0a/890a30f6-732b-4200-ac5b-acbd70567e14/ kozbeszerzesi_hatosag_2019_evi_beszamoloja.pdf (A letöltés dátuma: 2020. 11. 29.)

3. Bourn, John: Getting Value for Money from Procurement. UK, National Audit Office, 2001. Elérhetö: www.nao.org.uk/report/getting-value-for-money-from-procurementhow-auditors-can-help/ (A letöltés dátuma: 2017. 09. 11.)

4. Costa, João: The EU Procurement Directive. Dublin, IMSTA, 2015. Elérhető: www. slideshare.net/IMSTA/joao-costa-the-new-eu-procurement-directive-value-formoneyfinal (A letöltés dátuma: 2017. 10. 22.)

5. Draft recommendation of the Council on fighting bid rigging in public procurement. C(2012)115 - C(2012)115/CORR1, OECD, 2012. Elérhetö: www.one.oecd.org/document/ C(2012)115/en/pdf (A letöltés dátuma: 2017. 10. 20.)

6. Az EU és az Ön pénze. Európai Bizottság Magyarországi Képviselete, 2018. Elérhető: https://ec.europa.eu/hungary/about-us/eu-and-your-money_hu (A letöltés dátuma: 2020. 11. 29.)

7. Jackson, Penny: Value for Money and International Development: Deconstructing Myths to Promote a More Constructive Discussion. OECD, 2012.

8. Mchopa, Alban. D.: Integrating Contract Management Practices into the Achievement of Value for Money in Tanzania Public Procurement: Evidence from Selected Procuring Entities in Moshi Municipalit. Journal of Public Procurement, 15. (2015), 2. 129-149. DOI: 10.1108/JOPP-15-02-2015-B001

9. Office of Government Commerce (OGC): Working together to deliver better value. London, 2010. Elérhető: www.unpcdc.org/media/13787/workingtogethertodeliverbet tervalue.pdf (A letöltés dátuma: 2017. 10. 29.)

10. Rudzki, Robert A. - Smock, Douglas A. - Rogers, Stephen C. On-Demand Supply Management: World Class Strategies, Practices, and Technology. Fort Lauderdale, J. Ross Publishing, USA, 2007.

Jogi források

1. 2015. évi CXLIII. törvény a közbeszerzésekröl

2. Az Európai Parlament és a Tanács 2014/24/EU irányelve (2014. február 26.) a közbeszerzésről és a 2004/18/EK irányelv hatályon kívül helyezéséről 
Erdei-Derschner Katalin a Nemzeti Közszolgálati Egyetem Közigazgatás-tudományi Doktori Iskola nappali tagozatos hallgatója. Doktori tanulmányait 2016 szeptemberében kezdte, 10 év munkatapasztalat után stratégiai beszerzés, projektmenedzsment és beszerzési kategória menedzsment területén. Jelenleg fő kutatási témája a közbeszerzések hatékonyságának mérése, a közbeszerzések teljesítménymenedzsmentjének (gazdaságosság, eredményesség, hatékonyság és méltányosság), aspektusainak és alkalmazásai lehetőségének vizsgálata, mérési lehetőségeinek feltárása. 